\title{
VOLATILITY OF CHEMICAL ELEMENTS DURING THE DEHYDRATION OF SECONDARY SULFATES
}

\author{
Svetlana B. Bortnikova1, \\ BortnikivaSB@ipgg.sbras.ru
}

Natalya A. Abrosimova ${ }^{1}$, AbrosimovaNA@ipgg.sbras.ru

Anna Yu. Devyatova', DevyatovaAY@ipgg.sbras.ru

Elizaveta P. Shevko², Liza@igm.nsc.ru

\author{
Nataliya V. Yurkevich ${ }^{1}$, \\ YurkevichNV@ipgg.sbras.ru
}

Nikolay K. Cherny ${ }^{1}$, wulfgar.nk@gmail.com

Irina V. Danilenko², iv_danilenko@igm.nsc.ru

\section{Nadezhda A. Palchik2,} nadezhda@igm.nsc.ru

1 Trofimuk Institute of Petroleum Geology and Geophysics of the Siberian Branch of the RAS,

3, Ac. Koptyug avenue, Novosibirsk, 630090, Russia.

2 Sobolev Institute of Geology and Mineralogy of the Siberian Branch of the RAS,

3 , Ac. Koptyug avenue, Novosibirsk, 630090, Russia.

The relevance. Air pollution due to the activities of the mining and metallurgical industries is a serious problem for the environment. This study was conducted to determine the possible mechanisms of migration and the sources of elements in the atmosphere above the surface of tailings.

The main aim of the research is to show that chemical elements can be trapped by the water vapor and can migrate with the vapor phase during the desorption and dehydration of hydrous sulfates.

Object: samples from the surface of the Belovo waste heaps (Belovo zinc processing plant, Belovo, Russia).

Methods. Powder X-ray diffractometry (XRD) was used to determine the phase compositions of the crystalline substances, their quantitative phase relationships and transformations. An Agilent 8800 ICP-MS instrument (Tokyo, Japan), equipped with a MicroMist nebulizer, was used to determine the elements in the water samples (pore solution and condensates). Also, we used binocular microscope and physicochemical modeling methods.

Results. By analyzing the condensates, it was determined that a wide range of chemical elements can migrate with vapor-gas streams from secondary hydrous sulfates under relatively low-temperature conditions $\left(60^{\circ} \mathrm{C}\right)$. Condensate from the wet sample contains high element concentrations due to the input of elements from the pore solution and hydrous sulfates. Alterations in mineral structure and water release are indicated by losses of sample weight. With dehydration, cations and trace elements can be extracted from the crystal lattice, replaced by protons, and can then enter the vapor-gas phase when the solution evaporates.

\section{Key words:}

Secondary sulfates, pore solution, condensates, mine tailings, volatility of chemical elements.

\section{Introduction}

Studies of air pollution due to the activities of the mining and metallurgical industries are aimed at the investigation of wind erosion of the surface of tailings [1-9], the composition of aerosol particles of different dimensions [10-13], nanoparticles [14] and sulfur dioxide emissions [2]. A detailed analysis of the sources, forms of migration of elements in aerosols, and the extent of atmospheric pollution in the territories under the influence of the mining industry is contained in the review of J. Csavina et al. [15].

Concerning the gas component of sulfide technogenic bodies, most attention has been paid to oxygen as an oxidizing agent [16-19]. The problem of low-temperature migration of gases and metals from anthropogenic sources, particularly sulfide tailings, is poorly studied and discussed in the literature. Mainly, studies have investigated the gas transport of mercury [20-23], radon and thoron [24], as well as the production of greenhouse and sulfurcontaining gases [25]. A small number of studies have focused on the emission of sulfur gases and metalloids, such as antimony, tellurium, arsenic and bismuth [26-29]. The transfer of metals from tailings in the vapor-gas phase has been the focus of some works $[30,31]$.
Our previous work established that air streams over sulfide tailings are complex mixtures of sulfur-containing gases: sulfur dioxide, dimethyl sulfide, dimethyl selenide, carbon disulfide and others. Anomalies of these gases in the air above the sulfide tailings were detected by direct measurements using a portable gas analyzer GANK-4 and the gas chromato/mass spectrometer MCMS «NAVAL» after field gas collection on the sorbent [31-33]. In addition, inorganic components, including rock-forming elements $(\mathrm{Ca}, \mathrm{Mg}, \mathrm{Na}, \mathrm{K}, \mathrm{Si}, \mathrm{Fe}, \mathrm{Al}$, and $\mathrm{Mn})$, metals $(\mathrm{Cu}$, $\mathrm{Zn}, \mathrm{Pb}, \mathrm{Ni}$, and $\mathrm{Sn}$ ), and metalloids (As, Te, and $\mathrm{Sb}$ ), can migrate in a vapor-gas stream under ambient conditions. The elemental composition of low-temperature gas flows was determined by collecting condensates in situ using a special experimental setup with a Peltier refrigerator [34]. During laboratory experiments, we determined that chemical elements can be transferred by vapor-gas streams from both solutions and dry solid tailings. When the vapor separates from the solutions, the mobility of the elements depends on their chemical species. The potential for element migration in the vapor phase is determined by the percentage of hydrated ions; thus, as the proportion of aqua ions increases, the mobility of the element also in- 
creases. Furthermore, elements in complexes accumulate in the salt residue.

The concentrations of elements in condensates from solids increased depending on the oxidation state of the tailings matter, and there is a direct correlation with the amount of water-soluble species of elements [34]. It was shown that secondary sulfates forming on tailings surfaces can be a significant source of chemical elements because of their volatilization and transport by vapor-gas flows [34-36]. The investigation of sulfates and hydrated sulfate minerals plays a key role in the interpretation of the hydrochemical history of anthropogenic toxic tailings (and rock dumps) [36-41].

To understand the mechanism of element migration from sulfates, a determination of the composition of the vapor-gas mixture that separates from sulfates and a detailed study of the changes in some sulfates under slight heating were performed.

\section{Materials and methods}

For experiments with individual fractions of sulfates, the efflorescence samples were collected from the surface of the Belovo waste heaps (Belovo zinc processing plant, Belovo, Russia). The waste material of the plant is clinker, which is a product of pyrometallurgical smelting. The plant extracted $\mathrm{Zn}$ from a sphalerite concentrate, which was obtained from a polymetallic sulfide deposit mined in the Salair ore field. The mineralogy and internal structure of the Belovo waste heaps are described in detail in previous works [32, 42, 43]. Clinker is a loose, coarse-grained material resembling slag. It consists primarily of silicate glass with the inclusion of potassium feldspar, olivine, spinel, alloys and some amount of sulfides. Due to impurities in the original sphalerite concentrate, the clinker contains high levels of metals: up to $15 \%$ of $\mathrm{Zn}, 8,5 \%$ of $\mathrm{Cu}$, $0,7 \%$ of $\mathrm{Pb}$ and other metals and metalloids. A large amount of fine-grained coke breeze occurs in the waste material, which leads to spontaneous combustion in the inner part of the heaps $[32,39]$. Due to the high amount of remaining metals and the intensive transformation of the slags under the influence of oxidizing agents, intensified by combustion, abundant efflorescence consisting of sulfates of $\mathrm{Fe}, \mathrm{Cu}$, and $\mathrm{Zn}$ was formed on the surface.

\section{Field sampling}

During fieldwork under hot, dry weather conditions, efflorescence samples were collected from the surface of

substance of the lens

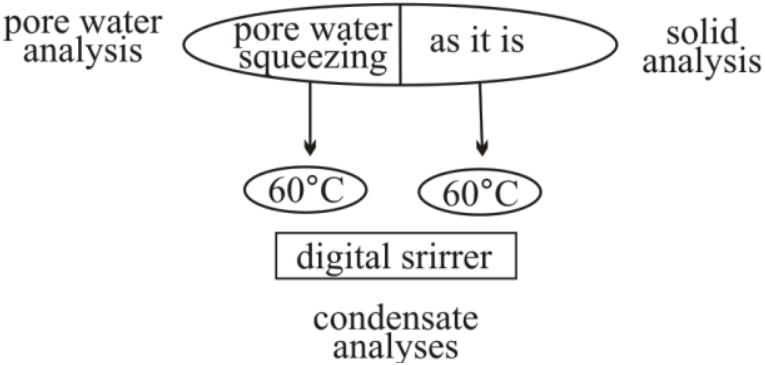

Fig. 2. Scheme of the laboratory experiments and analyses

Рис. 2. Схема лабораторных экспериментов и анализов the waste heaps (Fig. 1). A bulk sample consisting of intergrowths of sulfates was collected from a lens formed in clinker material. The sample was kept tightly packed in polyethylene bags to prevent contact with air and the evaporation of pore waters. Individual sulfates were taken from encrustation at the lens boundary and placed in sealed plastic containers.

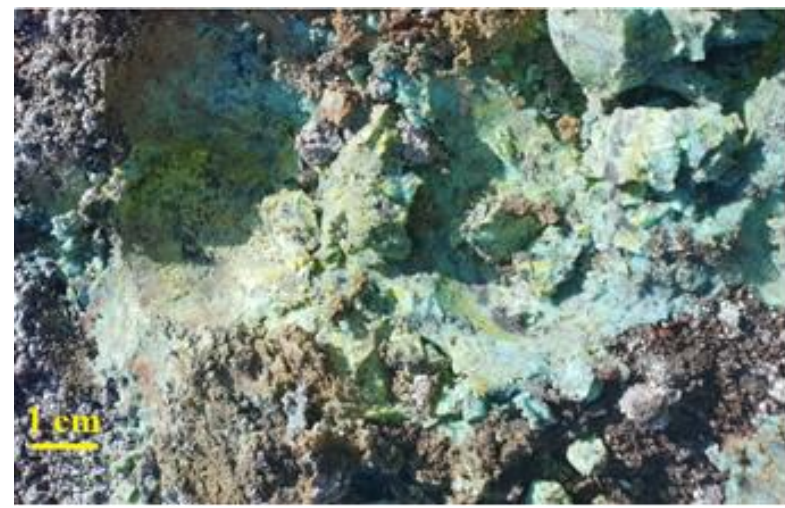

Fig. 1. Photograph of secondary sulfates on the heap surface

Рис. 1. Фотография линзы сульфатов на поверхности отвала

\section{Laboratory experiments and analyses}

The bulk sample was divided into two sets (Fig. 2). The first set was intended for pore solution squeezing and determination of liquid composition. The pore solution was squeezed from $0,5 \mathrm{~L}$ of the bulk sample using a laboratory press at pressure of $100 \mathrm{kPa}$. The second part of the sample was stored in a sealed package in a refrigerator before the experiment. The experiments were conducted on a dry sample consisting of a mixture of various sulfate minerals and on a wet sample containing a liquid phase in addition to sulfates.

To obtain condensates, $100 \mathrm{~g}$ of the bulk samples (before and after pore water squeezing) were placed in a heat-resistant beaker covered with a funnel that was connected to the bubbler inlet with a silicone hose (Fig. 2), An air-gas mixture was pumped out of the ice-cooled bubbler through an exit port by means of a back-pressure pump (pumping speed $\sim 2,41 / \mathrm{min}$ ). The beaker was heated to a temperature of $60{ }^{\circ} \mathrm{C}$ on the digital magnetic stirrer, and the condensates were dropped into the bubbler.

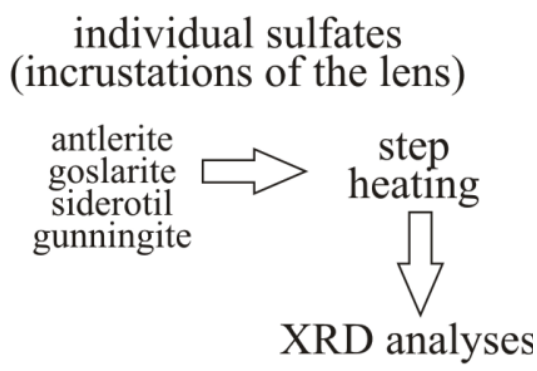


The contents of silicate group oxides in the bulk sample of the lens were determined via X-ray fluorescence analysis from a $3 \mathrm{~g}$ sample aliquot (IGM SB RAS, Laboratory of X-ray Spectral Analysis Methods). The elemental composition of the lens material was determined by energy-dispersive X-ray fluorescence analysis using synchrotron radiation (XRF-SR) at the Siberian Center for Synchrotron and Terahertz Radiation of the Center for Collective Use «SCSTI» at the INP SB RAS at the station of local and scanning X-ray fluorescence elemental analysis «Complex VEPP-4-VEPP-2000» [44].

An Agilent 8800 ICP-MS instrument (Tokyo, Japan), equipped with a MicroMist nebulizer, was used to determine the elements in the water samples (pore solution and condensates, NIIC SB RAS, Analytical Laboratory). High-purity Ar $(99,95 \%)$ was used as the plasmaforming, transporting, and cooling gas. A solution of $7 \mathrm{Li}$, $59 \mathrm{Co}, 89 \mathrm{Y}$, and $205 \mathrm{Tl}$ in $2 \%$ nitric acid, with a concentration of $1 \mathrm{~g} / \mathrm{L}$ for each determined element (Tuning Solution, USA), was used for the adjustment. All measure- ments were conducted in three replicates $(n=3)$ for each element. The relative standard deviation did not exceed $13 \%$ in all measurements.

Initially, a collection of samples, different in color and morphology, was set up for the study of individual sulfates (Fig. 3). Then, uniform grains were separated from each of the samples, neatly crushed in an agate mortar to a fraction of $0,1-0,25 \mathrm{~mm}$ and sorted by hand picking under a binocular microscope to achieve monomineral samples to the extent possible. Final samples were prepared for experiments as follows.

$100 \mathrm{mg}$ of each sample was abraded in an agate mortar into a powder with a particle size of approximately 10 $\mu \mathrm{m}$ with the addition of ethanol to preserve the structure. Then, the sample was applied to a glass substrate $25 \times 25$ $\mathrm{mm}$ in size with an even thick layer at the rate of $25 \mathrm{mg}$ per $1 \mathrm{~cm}^{2}$ of the substrate so that the layer thickness allowed us to analyze the sample directly, not the substrate. $\mathrm{X}$-ray phase analysis was carried out after drying the powder at room temperature.
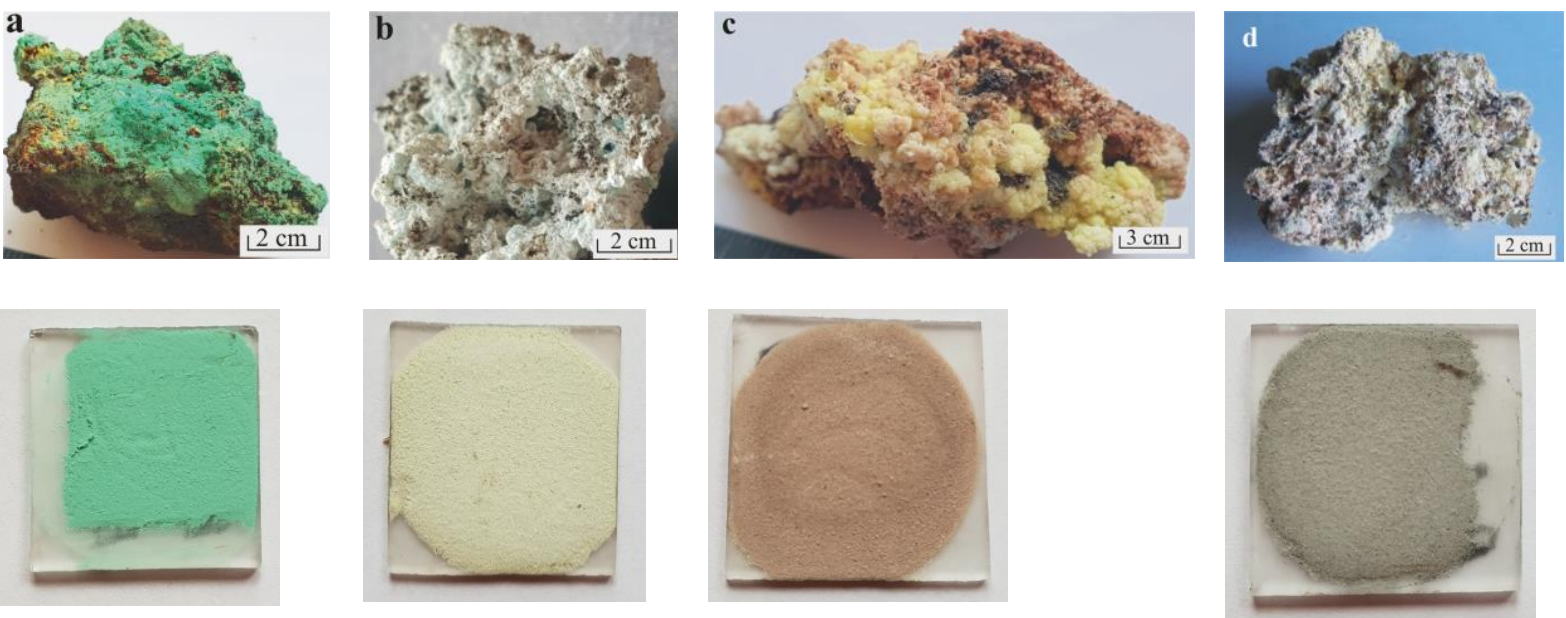

Fig. 3. Photographs of the studied sulfates: a) antlerite (BS-1); b) goslarite (BS-2); c) siderotil (BS-5); d) gunningite (BS-6), and prepared samples for XRD

Рис. 3. Фотографии исследуемых сульфатов: а) антлерит (BS-1); b) госларит (BS-2); c) сидеротил (BS-5); d) ганнингит (BS-6), и приготовленные препараты для РСТА

Each sample was heated on a digital magnetic stirrer WiseStir MSH-20D-Set (DAIHAN Scientific) at a temperature interval of $40-60^{\circ} \mathrm{C}$ for $1 \mathrm{~h}$ for each $10^{\circ} \mathrm{C}$ step under ambient air conditions. Before the experiments and after each heating step, the samples were weighed and measured. Powder X-ray diffractometry (XRD) was used to determine the phase compositions of the crystalline substances, their quantitative phase relationships and transformations. The XRD studies were performed on an ARL X'TRA powder diffractometer (Thermo Fisher Scientific, Ecublens, SARL, Switzerland) using $\mathrm{CuK}$ radiation, a voltage of $40 \mathrm{kV}$, and a current of $25 \mathrm{~mA}$. The diffraction patterns were scanned at $2 \theta$ intervals from 2 to $65^{\circ}$ in steps of 0,02 , and the analysis speed was 4 per minute.

\section{Physicochemical modeling}

To describe the chemistry of the interaction in the pore solution, equilibria were calculated in the temperature range from 20 to $60{ }^{\circ} \mathrm{C}$ with a step of $5{ }^{\circ} \mathrm{C}$. In the calculations, the software package «Selector» with a built-in thermodynamic database [45, 46] was used [47]. For each temperature step, we determined the dissolved species of all discussed elements and solid phases that could be formed in the solution under specified conditions. Thus, the features of the element behavior in the pore solution were determined, and the processes of precipitation/dissolution of the forming phases with increasing temperature were quantitatively described.

\section{Results}

Chemical and mineralogical composition of the bulk sample

The chemical composition of the lens material is dominated by $\mathrm{Cu}, \mathrm{Zn}$ and $\mathrm{Fe}$, which are the main mineralforming elements (Table 1). Sulfur accounts for almost $40 \%$. In addition to these elements, rather high concentrations of $\mathrm{Ni}, \mathrm{Co}$, and $\mathrm{As}$ are determined in the lens material. Rock-forming components ( $\mathrm{Si}, \mathrm{Al}, \mathrm{Ca}, \mathrm{Mn}$, etc.) are in small amounts. 
Table 1. Chemical composition of the lens

Таблица 1. Химический состав линзы

\begin{tabular}{|c|c|c|c|}
\hline $\begin{array}{c}\text { Elements } \\
\text { Элементы }\end{array}$ & $\%$ & $\begin{array}{c}\text { Elements } \\
\text { Элементы }\end{array}$ & $\begin{array}{c}\mathrm{ppm} \\
\Gamma / \mathrm{T}\end{array}$ \\
\hline $\mathrm{SiO}_{2}$ & 2,3 & $\mathrm{Ni}$ & 2540 \\
\hline $\mathrm{Al}_{2} \mathrm{O}_{3}$ & 0,34 & $\mathrm{Co}$ & 1850 \\
\hline $\mathrm{TiO}_{2}$ & 0,11 & $\mathrm{~Pb}$ & 36 \\
\hline $\mathrm{CaO}$ & 1,1 & $\mathrm{Ag}$ & 13 \\
\hline $\mathrm{MnO}$ & 0,42 & $\mathrm{Cd}$ & 2,7 \\
\hline $\mathrm{MgO}$ & 0,22 & $\mathrm{As}$ & 3200 \\
\hline $\mathrm{K}_{2} \mathrm{O}$ & 0,51 & $\mathrm{Sb}$ & 31 \\
\hline $\mathrm{Na}_{2} \mathrm{O}$ & 0,42 & $\mathrm{Te}$ & 1,3 \\
\hline $\mathrm{BaO}$ & 0,64 & $\mathrm{Sr}$ & 38 \\
\hline $\mathrm{Fe}$ & 10 & $\mathrm{Y}$ & 17 \\
\hline $\mathrm{Cu}$ & 20 & $\mathrm{Zr}$ & 13 \\
\hline $\mathrm{Zn}$ & 19 & $\mathrm{Mo}$ & 4,4 \\
\hline $\mathrm{S}$ & 39 & $\mathrm{Sn}$ & 2,8 \\
\hline
\end{tabular}

The mineral composition of the lens is a mixture of different sulfates of $\mathrm{Ca}, \mathrm{Cu}, \mathrm{Zn}, \mathrm{Fe}, \mathrm{Mg}, \mathrm{K}$, and $\mathrm{Na}$ (Ta- ble 2). The major minerals are aqueous sulfates that contain a different number of water molecules: chalcantite, goslarite, sideronatrite, starkeyite, siderotil, gunningite, and hydroxo-sulfate antlerite. Other crystalline hydrates of the same elements are present in smaller amounts. Traces of melanterite, dolerophanite, and lead and copper arsenate thometrekite were identified.

\section{The composition of the pore solution} and results of physicochemical modeling

The pore solution squeezed from the bulk sample is a highly mineralized acidic sulfate $\mathrm{Cu}-\mathrm{Zn}$ brine with high concentrations of $\mathrm{Na}, \mathrm{Fe}$, and $\mathrm{Mg}$ and total dissolved solids greater than $300 \mathrm{~g} / \mathrm{L}$. The main trace elements are $\mathrm{Mn}$ and As (Table 3). The high element concentrations in the pore water are the result of sulfide oxidation and sulfate dissolution in the waste material.

Table 2. Mineral composition of the lens

Таблица 2. Минеральный состав линзы

\begin{tabular}{|c|c|c|c|c|c|}
\hline \multicolumn{2}{|c|}{ Мајor/Основные } & \multicolumn{2}{|c|}{ Minor/Второстепенные } & \multicolumn{2}{|c|}{ Trace/Следы (<<1 \%) } \\
\hline $\begin{array}{c}\text { Antlerite } \\
\text { Антлерит }\end{array}$ & $\begin{array}{c}\mathrm{Cu}_{3}\left(\mathrm{SO}_{4}\right)(\mathrm{OH})_{4} \\
\sim 40 \pm 5 \% \\
\end{array}$ & $\begin{array}{c}\text { Mirabilite } \\
\text { Мирабилит }\end{array}$ & $\begin{array}{c}\mathrm{Na}_{2} \mathrm{SO}_{4} \times 10 \mathrm{H}_{2} \mathrm{O} \\
\approx 2 \pm 0,3 \%\end{array}$ & $\begin{array}{c}\text { Melanterite } \\
\text { Мелантерит }\end{array}$ & $\mathrm{FeSO}_{4} \times 7 \mathrm{H}_{2} \mathrm{O}$ \\
\hline $\begin{array}{l}\text { Goslarite } \\
\text { Госларит }\end{array}$ & $\begin{array}{c}\mathrm{Zn}\left(\mathrm{SO}_{4}\right) \times 7 \mathrm{H}_{2} \mathrm{O} \\
\sim 20 \pm 5 \%\end{array}$ & $\begin{array}{l}\text { Moorhouseite } \\
\text { Мурхаузит }\end{array}$ & $\begin{array}{c}(\mathrm{Co}, \mathrm{Ni}, \mathrm{Mn}) \mathrm{SO}_{4} \times 6 \mathrm{H}_{2} \mathrm{O} \\
\approx 1 \pm 0,1 \%\end{array}$ & $\begin{array}{l}\text { Dolerophanite } \\
\text { Долерофанит }\end{array}$ & $\mathrm{Cu}_{2} \mathrm{O}\left(\mathrm{SO}_{4}\right)$ \\
\hline $\begin{array}{l}\text { Gunningite } \\
\text { Ганнингит }\end{array}$ & $\begin{array}{c}\mathrm{ZnSO}_{4} \times \mathrm{H}_{2} \mathrm{O} \\
\sim 15 \pm 2 \%\end{array}$ & $\begin{array}{l}\text { Gypsum } \\
\text { Гипс }\end{array}$ & $\begin{array}{c}\mathrm{CaSO}_{4} \times 2 \mathrm{H}_{2} \mathrm{O} \\
\approx 1 \pm 0,1 \%\end{array}$ & $\begin{array}{l}\text { Thometrekite } \\
\text { Тометрекит }\end{array}$ & $\begin{array}{c}\mathrm{PbCu}_{2}\left(\mathrm{AsO}_{4}\right)_{2} \times 2 \mathrm{H}_{2} \\
\mathrm{O}\end{array}$ \\
\hline $\begin{array}{c}\text { Siderotil } \\
\text { Сидеротил }\end{array}$ & $\begin{array}{c}\mathrm{Fe}\left(\mathrm{SO}_{4}\right) \times 5 \mathrm{H}_{2} \mathrm{O} \\
\sim 10 \pm 2 \% \\
\end{array}$ & $\begin{array}{l}\text { Bianchite } \\
\text { Бианхит }\end{array}$ & $\begin{array}{c}(\mathrm{Zn}, \mathrm{Fe}) \mathrm{SO}_{4} \times 6 \mathrm{H}_{2} \mathrm{O} \\
\quad \approx 1 \pm 0,1 \%\end{array}$ & & \\
\hline $\begin{array}{l}\text { Starkeyite } \\
\text { Старкиит }\end{array}$ & $\begin{array}{l}\mathrm{MgSO}_{4} \times 4 \mathrm{H}_{2} \mathrm{O} \\
\sim 3 \pm 0,5 \%\end{array}$ & $\begin{array}{l}\text { Cуаnоcroite } \\
\text { Цианокроит }\end{array}$ & $\begin{array}{l}\mathrm{K}_{2} \mathrm{Cu}\left(\mathrm{SO}_{4}\right)_{2} \times 6 \mathrm{H}_{2} \mathrm{O} \\
\quad \approx 0,4 \pm 0,1 \%\end{array}$ & & \\
\hline $\begin{array}{c}\text { Sideronatrite } \\
\text { Сидеронатрит }\end{array}$ & $\begin{array}{c}\mathrm{Na}_{2} \mathrm{Fe}\left(\mathrm{SO}_{4}\right)_{2}(\mathrm{OH}) \times 3 \mathrm{H}_{2} \mathrm{O} \\
\sim 2 \pm 0,3 \%\end{array}$ & & & & \\
\hline
\end{tabular}

Note/Примечание: *-approximate content in the sample/nриблизительное содержание в образие.

Table 3. Element concentrations in the pore solution, $m g / L$

Таблица 3. Концентрации элементов в поровом растворе, мг/л

\begin{tabular}{|c|c|c|c|}
\hline $\begin{array}{c}\text { Elements } \\
\text { Элементы }\end{array}$ & $\begin{array}{c}\text { Content } \\
\text { Содержание }\end{array}$ & $\begin{array}{c}\text { Elements } \\
\text { Элементы }\end{array}$ & $\begin{array}{c}\text { Content } \\
\text { Содержание }\end{array}$ \\
\hline $\mathrm{SO}_{4}^{2-*}$ & 187 & $\mathrm{Si}$ & 29 \\
\hline $\mathrm{Ca}$ & 360 & $\mathrm{Cd}$ & 19 \\
\hline $\mathrm{Mg}^{*}$ & 8,6 & $\mathrm{Cr}$ & 16 \\
\hline $\mathrm{Na}^{*}$ & 15 & $\mathrm{Co}$ & 82 \\
\hline $\mathrm{K}$ & 23 & $\mathrm{As}$ & 870 \\
\hline $\mathrm{Fe}^{*}$ & 13 & $\mathrm{Sb}$ & 14 \\
\hline $\mathrm{Mn}$ & 970 & $\mathrm{Ba}$ & 0.46 \\
\hline $\mathrm{Al}^{*}$ & 1,2 & $\mathrm{Sr}$ & 1,8 \\
\hline $\mathrm{Cu}^{*}$ & 29 & $\mathrm{Ti}$ & 3,6 \\
\hline $\mathrm{Zn}^{*}$ & 47 & $\mathrm{~V}$ & 3,8 \\
\hline
\end{tabular}

*-elements in g/L/элементы в г/л.

The calculation of equilibria in a solution with this composition using physicochemical modeling was carried out to describe the chemistry of the element behavior in the experiments. The results indicate the complexity of redistribution of elements between the true solution and the resulting solid phases during heating. In the temperature range under discussion, the elements $\mathrm{Mg}, \mathrm{Mn}, \mathrm{Na}, \mathrm{Cd}, \mathrm{Al}$, and $\mathrm{Co}$ were completely in solution (Fig. 4). However, their species were different. $\mathrm{Mg}$ and $\mathrm{Mn}$ were in two main forms: $\mathrm{Me}^{2+}$ and $\mathrm{MeSO}_{4}(\mathrm{aq})$; the sulfate complex was predominant, and the aqua ion form was 3-9 \% of the total content. The forms of $\mathrm{Na}$ are almost evenly distributed between the anionic sulfate complex $\mathrm{MeSO}_{4}$ and the $\mathrm{Me}^{+}$aqua ions. Cadmium and cobalt are almost entirely in the form of aqua ions: $\mathrm{Cd}^{2+}$ and $\mathrm{Co}^{2+}$. Arsenic in solution is present in the form of metaarsenous acid $\left(\mathrm{HAsO}_{2}\right)$, a highly toxic compound of $\mathrm{As}(\mathrm{III})$. Vanadium forms the vanadil-ion $\mathrm{VO}^{2+}$.

In contrast to the described elements, $\mathrm{Ca}, \mathrm{Sr}$, and the metals $\mathrm{Cu}, \mathrm{Zn}$, and $\mathrm{Fe}$ in the pore solution can form a solid suspension, and their amount in the true dissolved form changes with increasing temperature. The percentage of dissolved $\mathrm{Ca}$ decreases from 28 to $15 \%$ with increasing temperature from 20 to $60{ }^{\circ} \mathrm{C}$ (Fig. 5), and an anhydrite suspension may be formed. Thus, a major amount of dissolved $\mathrm{Ca}(97 \%)$ forms a neutral sulfate complex, and only $3 \%$ is in the form of aqua ions. The percentage of dissolved $\mathrm{Sr}$ as a whole decreases from 61 to $26 \%$, although in the range of $20-45^{\circ} \mathrm{C}$ the solubility of its compounds increases, reaching a maximum at $45^{\circ} \mathrm{C}$, but then it goes into suspension in the form of celestine with increasing temperature and remains completely in solution in aqua-ionic form. $\mathrm{Cu}, \mathrm{Zn}$, and $\mathrm{Fe}$ at $20{ }^{\circ} \mathrm{C}$ actively interact with $\mathrm{SO}_{4}{ }^{2-}$, forming a suspension of sulfates (chalcanthite, goslarite, and melanterite) at the beginning of heating, which then is dissolved at $50-60{ }^{\circ} \mathrm{C}$, and the metals are released into solution as aqua-ionic species (Fig. 5). Antimony is precipitated in the form of servantite $\left(\mathrm{Sb}_{2} \mathrm{O}_{4}\right)$, and no more than $1,5 \%$ of the total content in solution is in the form of meta-antimony acid. 


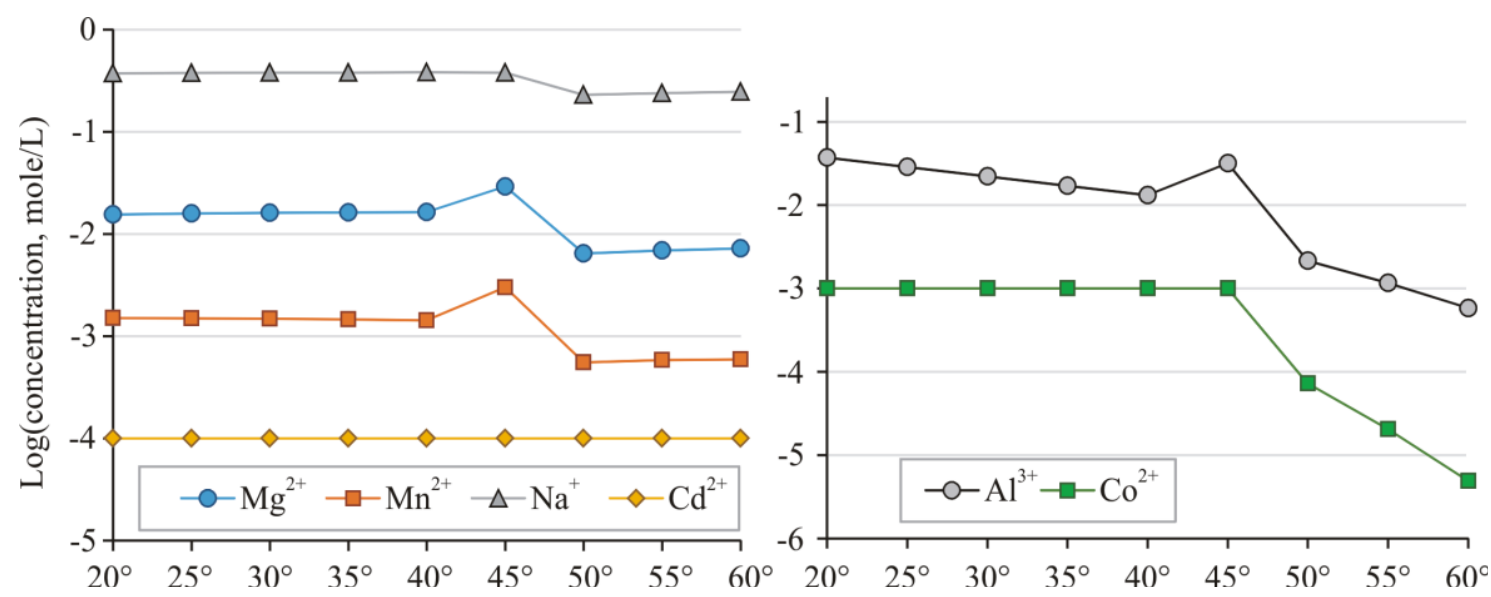

Fig. 4. Concentration of element aqua-ions in the pore solution when heating

Рис. 4. Концентрация аква-ионных форм в поровом растворе при нагревании
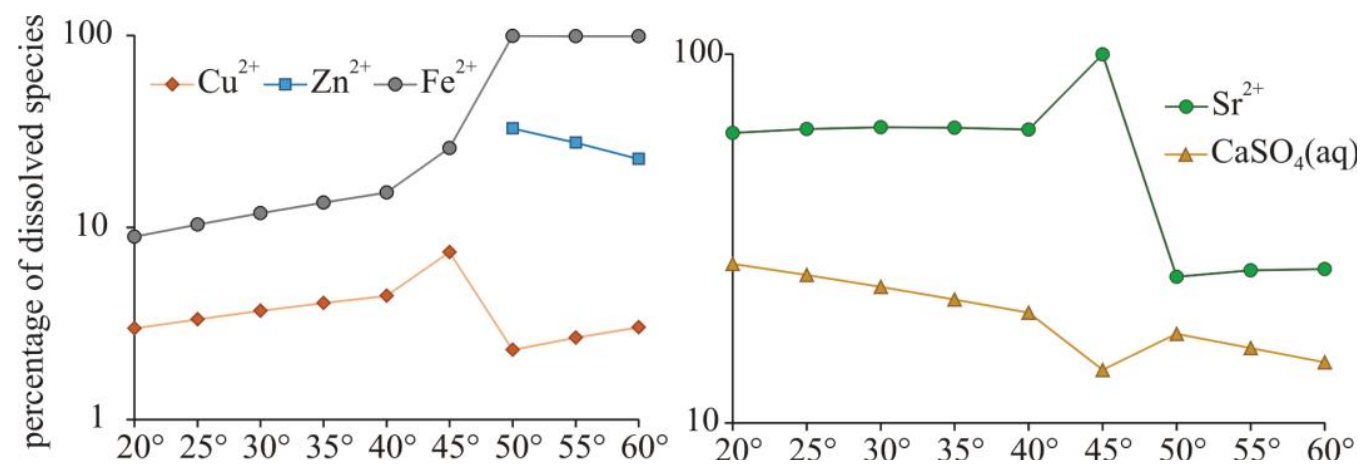

Fig. 5. Changes in the dissolved forms of elements with increasing temperature

Puc. 5. Изменение растворенных форм элементов с увеличением температуры

\section{Composition of condensates}

The obtained condensates from both wet (before pore water squeezing - BL-1) and dry (after squeezing - BL-2) samples contain a wide range of elements (Table 4).

Table 4. Element concentrations in condensates, $\mathrm{Ca}-\mathrm{Sr}$ in $\mathrm{mg} / \mathrm{L} ; \mathrm{Al}-\mathrm{Li}$ in $\mu \mathrm{g} / \mathrm{L}$

Таблица 4. Концентрации элементов в конденсатах, $\mathrm{Ca}-\mathrm{Sr}$ в $\mathrm{Mz} / \mathrm{s} ; \mathrm{Al}-\mathrm{Li}$ в $\mu г / л$

\begin{tabular}{|c|c|c|c|c|c|}
\hline & BL-1 & BL-2 & & BL-1 & BL-2 \\
\hline $\mathrm{Ca}$ & 1,8 & 1,1 & $\mathrm{Al}$ & 5,2 & 4,6 \\
\hline $\mathrm{Mg}$ & 0,39 & 0,16 & $\mathrm{Cd}$ & 1,6 & 3,0 \\
\hline $\mathrm{Na}$ & 0,25 & 0,18 & $\mathrm{Cr}$ & 0,19 & 1,9 \\
\hline $\mathrm{K}$ & 0,30 & 0,25 & $\mathrm{Co}$ & 0,58 & 0,50 \\
\hline $\mathrm{Fe}$ & 0,013 & $<0,005$ & $\mathrm{Ag}$ & 0,052 & 0,021 \\
\hline $\mathrm{Mn}$ & 0,034 & 0,034 & $\mathrm{As}$ & 10 & 7,9 \\
\hline $\mathrm{Si}$ & 0,45 & 0,38 & $\mathrm{Sb}$ & 0,092 & 0,025 \\
\hline $\mathrm{Cu}$ & 0,089 & 0,030 & $\mathrm{Rb}$ & 0,65 & 0,76 \\
\hline $\mathrm{Zn}$ & 0,11 & 0,023 & $\mathrm{Ti}$ & 0,31 & 0,29 \\
\hline $\mathrm{Ba}$ & 0,0077 & 0,0048 & $\mathrm{~V}$ & $<0,3$ & 0,74 \\
\hline $\mathrm{Sr}$ & 0,011 & 0,0072 & $\mathrm{Li}$ & 0,38 & 0,36 \\
\hline
\end{tabular}

Calcium is the major cation, and $\mathrm{Mg}, \mathrm{Na}, \mathrm{Si}$, and $\mathrm{K}$ are less abundant. Among the metals, the highest concentrations are found for $\mathrm{Zn}$ and $\mathrm{Cu}$ as mineral-forming elements. At the same time, the concentration of iron is much lower than we would expect. The concentration of iron is below the detection limit in the condensate from the dry sample, although the sample contains hydrous ferrous minerals, i. e. sideronatrite and siderotil, and iron is present as an impurity in all other sulfates. The low volatility of iron in comparison with other metals was noted previously [31, 32]. Trace elements, such as $\mathrm{Ba}, \mathrm{Sr}, \mathrm{Al}$, and As, are determined in condensates at low but measurable concentrations. This means that chemical elements, both main mineral-forming and trace elements, are capable of being captured by water and migrating with the vapor phase.

\section{Sample mineralogy and its transformation under heating}

To detail the separation of the vapor-gas mixture from the solid, individual mineral phases were studied. Experiments to determine changes in minerals when heated were performed with reference to various sulfates that make up the lens. Experimental mineral samples consist of secondary hydrous sulfates of $\mathrm{Cu}, \mathrm{Zn}, \mathrm{Fe}$, and $\mathrm{Mg}$ (Table 5).

In addition to the main mineral-forming elements, sulfates contain admixtures of many metals and metalloids and thin mutual intergrowths due to the complex composition of pore solutions from which they were crystallized. The typical admixtures in goslarite are $\mathrm{Cu}, \mathrm{Ni}, \mathrm{Fe}, \mathrm{Al}, \mathrm{K}$, and $\mathrm{Ca}$, and the elements $\mathrm{As}, \mathrm{Ba}$, and $\mathrm{Co}$ are less common. Siderotil contains $\mathrm{Cu}, \mathrm{Zn}, \mathrm{Ni}, \mathrm{Co}, \mathrm{Mn}, \mathrm{Mg}$, and $\mathrm{Ag}$. Starkeyite is characterized by elevated concentrations of $\mathrm{Cu}, \mathrm{Zn}, \mathrm{Ni}, \mathrm{Fe}$, and $\mathrm{Mn}$.

The first step of heating (at $40{ }^{\circ} \mathrm{C}$ ) led to a reduction in weight in all of the studied samples. The greatest weight loss $(23 \%)$ was recorded in sample BS-2, consist- 
ing mainly of goslarite with impurities of sideronatrite and cyanochroite. Samples BS-5 and BS-6 became $13 \%$ lighter. In addition, antlerite (sample BS-1) lost only 0,18\% of its weight (Table 5).
As follows from the results of XRD analyses, the diffraction pattern of antlerite after heating at 40 and $50{ }^{\circ} \mathrm{C}$ remained without alteration based on comparison with the initial pattern (Fig. 6). A slight weight reduction occurred due to the separation of sorbed water.

Table 5. Transformation of minerals of the studied samples during heating

Таблица 5. Изменение минералов изучаемых образиов при нагревании

\begin{tabular}{|c|c|c|c|c|c|c|}
\hline \multirow{3}{*}{ No } & \multirow{3}{*}{$\begin{array}{l}\text { Mineral } \\
\text { Минерал }\end{array}$} & \multirow{3}{*}{$\begin{array}{l}\text { Formula } \\
\text { Формула }\end{array}$} & \multicolumn{4}{|c|}{$\begin{array}{l}\text { transformation during heating } \\
\text { преобразование во время нагрева }\end{array}$} \\
\hline & & & \multicolumn{2}{|r|}{$40^{\circ} \mathrm{C}$} & \multicolumn{2}{|c|}{$50^{\circ} \mathrm{C}$} \\
\hline & & & $\begin{array}{l}\text { w.1., } \% \\
\text { ппн, \% }\end{array}$ & $\begin{array}{c}\text { new-formed minerals } \\
\text { новообразованные } \\
\text { минералы }\end{array}$ & $\begin{array}{l}\text { w.1., \% } \\
\text { ппп, \% }\end{array}$ & $\begin{array}{c}\text { new-formed minerals } \\
\text { новообразованные } \\
\text { минералы }\end{array}$ \\
\hline BS-1 & $\begin{array}{c}\text { antlerite } \\
\text { антлерит }\end{array}$ & $\mathrm{Cu}_{3}\left(\mathrm{SO}_{4}\right)(\mathrm{OH})_{4}$ & 0,18 & $\begin{array}{c}\text { n.a. } \\
\text { б.изм. }\end{array}$ & 1,4 & $\begin{array}{c}\text { n.a. } \\
\text { б.изм. }\end{array}$ \\
\hline \multirow{3}{*}{ BS-2 } & $\begin{array}{l}\text { goslarite } \\
\text { госларит }\end{array}$ & $\mathrm{Zn}\left(\mathrm{SO}_{4}\right) \times 7 \mathrm{H}_{2} \mathrm{O}$ & \multirow{3}{*}{23} & $\begin{array}{c}\text { gunningite } \\
\mathrm{ZnSO}_{4} \times \mathrm{H}_{2} \mathrm{O} \\
\text { ганнингит }\end{array}$ & \multirow{3}{*}{7,8} & $\begin{array}{l}\text { n.a. } \\
\text { б.изм. }\end{array}$ \\
\hline & $\begin{array}{l}\text { sideronatrite } \\
\text { сидеронатрит }\end{array}$ & $\mathrm{Na}_{2} \mathrm{Fe}\left(\mathrm{SO}_{4}\right)_{2}(\mathrm{OH}) \times 3 \mathrm{H}_{2} \mathrm{O}$ & & $\begin{array}{c}\mathrm{Na} \text {-jarosite } \\
\mathrm{NaFe}_{3}\left(\mathrm{SO}_{4}\right)_{2}(\mathrm{OH})_{6} \\
\mathrm{Na} \text {-ярозит } \\
\end{array}$ & & $\begin{array}{l}\text { n.a. } \\
\text { б.изм. }\end{array}$ \\
\hline & $\begin{array}{l}\text { cyanochrocite } \\
\text { цианохрокит }\end{array}$ & $\mathrm{K}_{2} \mathrm{Cu}\left(\mathrm{SO}_{4}\right)_{2} \times 6 \mathrm{H}_{2} \mathrm{O}$ & & $\begin{array}{c}\text { poitevinite } \\
(\mathrm{Cu}, \mathrm{Fe}) \mathrm{SO}_{4} \times \mathrm{H}_{2} \mathrm{O} \\
\text { поитевинит }\end{array}$ & & $\begin{array}{c}\text { brochantite } \\
\mathrm{Cu}_{4}\left(\mathrm{SO}_{4}\right)(\mathrm{OH})_{6} \\
\text { брошантит } \\
\end{array}$ \\
\hline \multirow[b]{2}{*}{ BS-5 } & $\begin{array}{c}\text { siderotil } \\
\text { сидеротил }\end{array}$ & $\mathrm{Fe}\left(\mathrm{SO}_{4}\right) \times 5 \mathrm{H}_{2} \mathrm{O}$ & \multirow[b]{2}{*}{13} & $\begin{array}{c}\text { became less } \\
\text { стало меньше }\end{array}$ & \multirow[b]{2}{*}{8,9} & $\begin{array}{c}\text { parabutlerite } \mathrm{Fe}\left(\mathrm{SO}_{4}\right) \times 2 \mathrm{H}_{2} \mathrm{O} \\
\text { парабутлерит }\end{array}$ \\
\hline & $\begin{array}{l}\text { starkeyite } \\
\text { старкеит }\end{array}$ & $\mathrm{MgSO}_{4} \times \mathrm{H}_{2} \mathrm{O}$ & & $\begin{array}{c}\text { structure was loosened } \\
\text { структура } \\
\text { разрыхлилась }\end{array}$ & & $\begin{array}{c}\text { structure was even more loos- } \\
\text { ened } \\
\text { структура еще } \\
\text { более разрыхлилась }\end{array}$ \\
\hline BS-6 & $\begin{array}{l}\text { gunningite } \\
\text { ганнингит }\end{array}$ & $\mathrm{ZnSO}_{4} \times \mathrm{H}_{2} \mathrm{O}$ & 13 & $\begin{array}{c}\text { n.a. } \\
\text { б.изм. }\end{array}$ & 19 & $\begin{array}{c}\text { n.a. } \\
\text { б.изм. }\end{array}$ \\
\hline
\end{tabular}

Note: w.l. - weight losses; n.a. - no alteration.

Примечание: ппн - потеря веса при нагревании; б.изм. - без изменений.

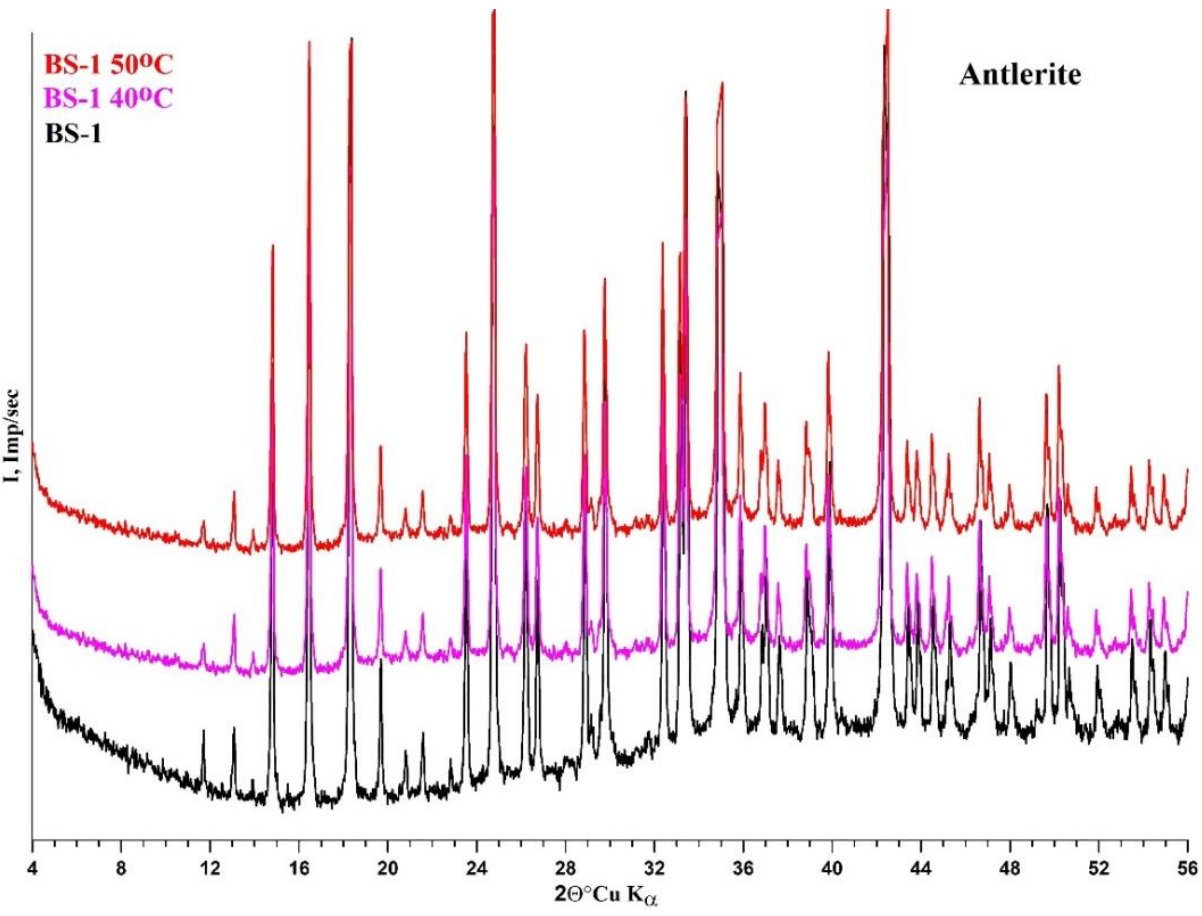

Fig. 6. Diffraction patterns of sample BS-1

Pис. 6. Дифрактограмма образиа BS-1

However, the diffraction pattern of sample BS-2 changed significantly (Fig. 7, a). At the first step of heating $\left(40{ }^{\circ} \mathrm{C}\right)$, peaks of some minerals disappeared (goslar- ite, sideronatrite, and cyanochroite), and peaks of other minerals appeared (Na-jarosite, gunningite, and poitevinite+brochantite). Obviously, this process occurred 
due to the separation of molecules of structural $\mathrm{H}_{2} \mathrm{O}$ and the transformation of the minerals to another phase. At the second heating step $\left(50{ }^{\circ} \mathrm{C}\right)$, the diffraction pattern was insignificantly altered, and changes were related to reciprocal substitutions of poitevinite-brochantite.

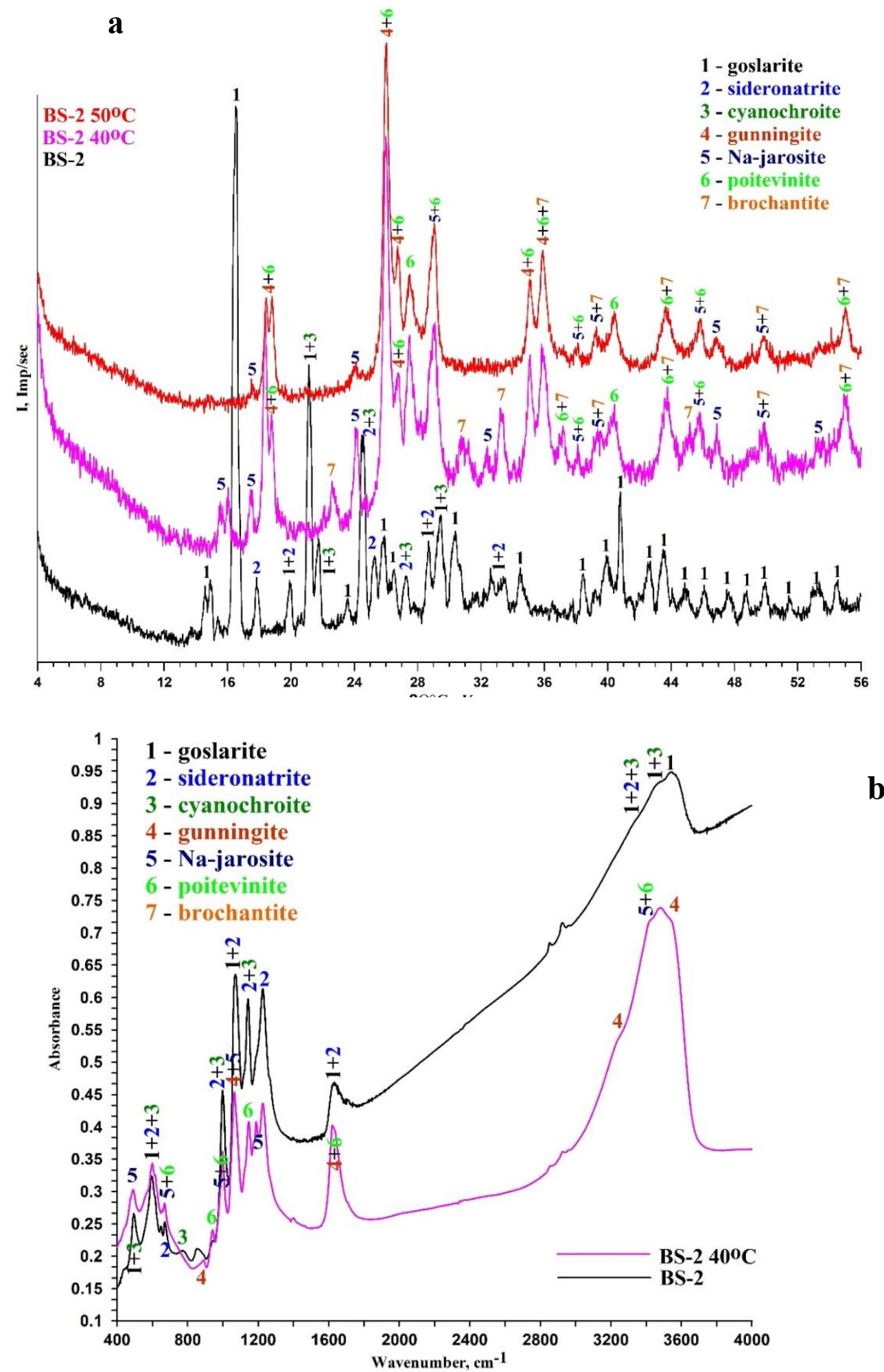

Fig. 7. a) diffraction patterns of sample BS-2; b) comparative IR spectrum of the initial sample BS-2 and heated to $40^{\circ} \mathrm{C}$ Puc. 7. а) дифрактограмма образиа BS-2; b) сравнение ИК-спектров исходного образиа и после нагрева до $40^{\circ} \mathrm{C}$

To confirm the mineral transformations for this sample, we compared the IR data of the initial sample and the sample heated to $40{ }^{\circ} \mathrm{C}$ (Fig. 7, b). The characteristic ab- sorption bands of goslarite, sideronatrite and cyanochroite are clearly visible in the initial spectrum. In the sample heated to $40{ }^{\circ} \mathrm{C}$, the transitions of goslarite to gunningite, 
sideronatrite to Na-jarosite, and cyanochroite to poitevinite are noticeable.

Sample BS-5 was mainly siderotil, and starkeyite was a minor phase. After heating at $40{ }^{\circ} \mathrm{C}$, the amount of siderotil decreased, and only traces remained (Fig. 8). The first peaks of parabutlerite appeared, indicating the separation of $3 \mathrm{H}_{2} \mathrm{O}$ molecules from siderotil and its transformation to a new phase. Starkeyite began to prevail in the sample, but its structure became less clear. Then, at $50{ }^{\circ} \mathrm{C}$, the siderotil disappeared completely and was replaced by parabutlerite, and the structure of starkeyite became even looser.

Sample BS-6, consisting of mainly gunningite and siderotil as a minor phase, was partly altered (Fig. 9). Gunningite remained without alteration at 40 and $50{ }^{\circ} \mathrm{C}$, but peaks of siderotil disappeared. As in sample BS-2, weight loss was caused by the release of sorbed and structural water.

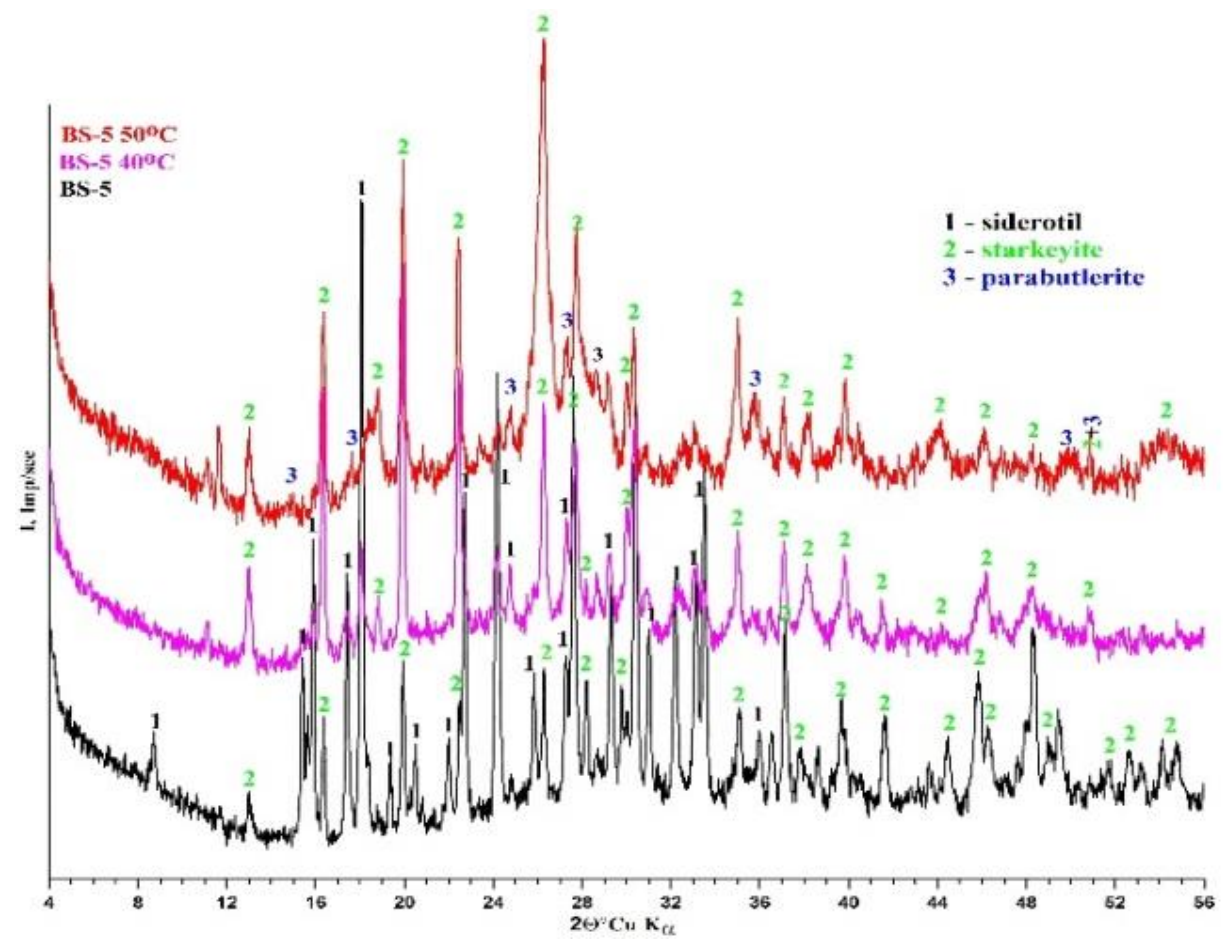

Fig. 8. Diffraction patterns of sample BS-5

Puc. 8. Дифрактограмма образиа BS-5

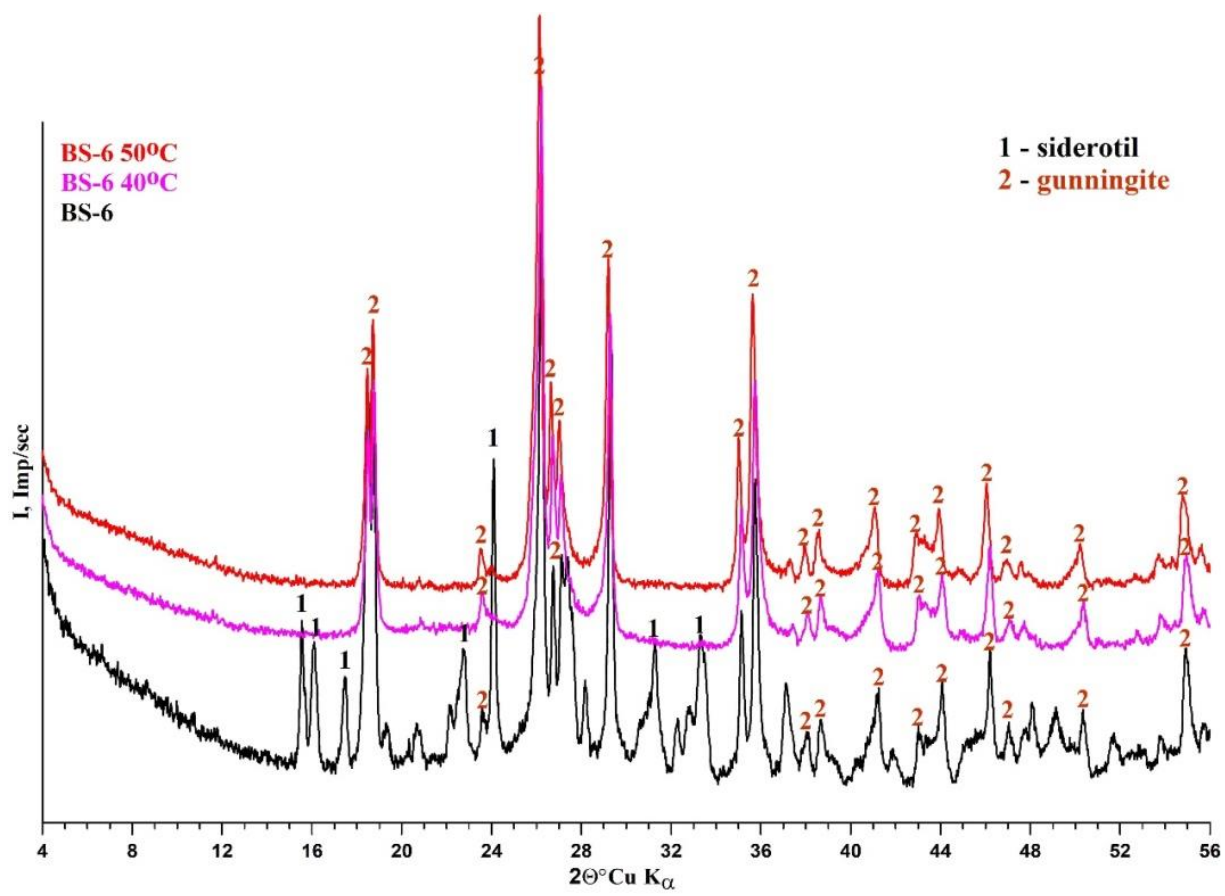

Fig. 9. Diffraction patterns of sample BS-6

Puc. 9. Дифрактограмма образиа BS-6 


\section{Discussion}

From the resulting X-ray diffractograms, the scheme of mineral transformation can be presented as follows (Fig. 10). In sample BS-2, goslarite lost 6 molecules of water and transformed to gunningite. It is known that during dehydration, goslarite first transitions into bianchite 6 aqueous sulfate, then into boleyte, and only then into guanningite [48, 49]. In our experiment, goslarite transformed into gunningite instantaneously. Sideronatrite lost 3 water molecules and was replaced by $\mathrm{Na}$-jarosite. In addition, cyanochroite transformed to poitevinite after the loss of 5 water molecules. In total, the sample lost $23 \%$ of its weight due to separation of sorbed and structural water. At the next temperature step, weight loss was due to separation of sorbed water only and therefore was much less. In sample BS-5, siderotil began to decompose at $40{ }^{\circ} \mathrm{C}$ (Fig. 11). Its amount became less due to the separation of 3 water molecules, and the first grains of parabutlerite appeared; then, at $50{ }^{\circ} \mathrm{C}$, it replaced siderotil completely. The structure of starkeyite was loosened. Thus, the weight losses of this sample were mainly due to the separation of sorbed water, with a small contribution of the loss of structural water.

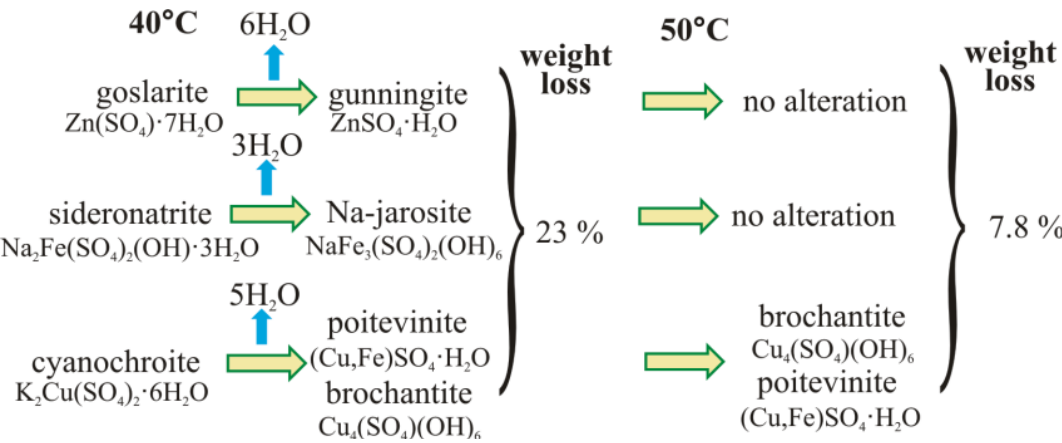

Fig. 10. Scheme of mineral transformation upon heating sample BS-2

Pис. 10. Схема изменений минералов при нагревании образиа BS-2

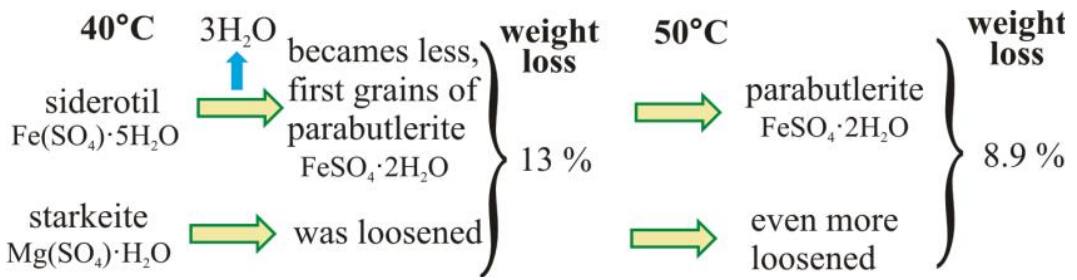

Fig. 11. Scheme of mineral transformation upon heating sample BS-5

Pис. 11. Схема изменений минералов при нагревании образияа BS-5

Thus, collected condensate from the dry sample is both sorbed and structural water is released during sample heating. Condensate from the wet sample also contains some part of water from the pore solution and is characterized by higher concentrations of almost all elements, obviously due to the input of elements from two sources: the solid matter (sulfate minerals) and the pore solution. However, the excess concentrations of elements in condensates from the wet sample are not as large as one would expect, based on the high salinity of the pore solution. The concentrations of $\mathrm{Cd}, \mathrm{Cr}, \mathrm{Rb}$, and $\mathrm{V}$ are higher in the condensate obtained from the dry samples. The concentrations of $\mathrm{Mn}, \mathrm{Li}, \mathrm{K}, \mathrm{Ti}$, and $\mathrm{Co}$ are almost the same in both types of condensates.

A wide variety of element species in the pore solution and the highly active interactions determine the complexity of their behavior during the separation of the vapor phase and the absence of correlation between the total element concentrations in the solution and in the resulting condensate. Some features of the condensate composition, and therefore, the behavior of the elements during the separation of the vapor phase from the solution, were explained by the analysis of the results of physicochemical modeling. In general, rather similar concentrations of elements in condensates from the wet and dry samples are apparently determined by the element speciation in the pore solution, namely, the high percentage of sulfate complexes of most elements. As our previous research has shown, water vapor transports elements in the form of aqueous ions, whereas complexed species (such as Me$\mathrm{SO}_{4}(\mathrm{aq}), \mathrm{Me}(\mathrm{OH})$, etc.) are characterized by inert behavior during separation of the vapor phase and remain in the salt residue [34]. In particular, the low $\mathrm{V}$ concentrations in condensates from the wet sample were caused by the formation of vanadyl ions in a solution, which are less mobile than the aqua ions. The phase composition is of great importance and determines whether an element is found in true solution or in the form of a suspension. As numerical modeling showed, many of the elements under discussion are able to form solid phases in the pore solution and can then be dissolved or precipitated. The inert behavior of iron, as mentioned before, is a mystery because at the temperature of the experiment $\left(60{ }^{\circ} \mathrm{C}\right), 99 \%$ of the iron is in the dissolved form, and the aqua ion $\mathrm{Fe}^{2+}$, by analogy with other metals, should be rather mobile. 
The observed features of the vapor phase composition from the dry sample were apparently determined by the crystalline structure of the minerals. The effect of leaching cations and admixtures from minerals is known to occur when minerals interact with water. The cations then go into solution and are replaced by $\mathrm{H}^{+}$ions. Such a reaction can occur in the near-surface layer of a mineral when it comes into contact with water sorbed on the surface of the grain. The increase in temperature accelerates the dissolution of the surface of grains by sorbed water and the transfer of elements into the solution, which then evaporates in the form of a vapor-gas phase. In this case, condensation of the formed vapors on less heated areas of the surface and structural defects are possible because the sample is heated unevenly. The condensed vapors also interact with the grains, and further dissolution occurs.

Using physicochemical calculation of equilibrium during the heating of goslarite, the phase transition observed in the experiment was itemized and quantitatively described. The temperature of transition of goslarite to gunningite in the calculations was $45^{\circ} \mathrm{C}$, while approximately $1 \%$ of zinc contained in the mineral passed into the separated structural water in aqua ion form. Further transport of zinc into the vapor phase can possibly occur by a mechanism comparable to the flotation. Water molecules can act as flotation reagents, capturing zinc ions and lifting them into the vapor phase.

When hydrous sulfates are heated, dehydration occurs, and water, which is part of the mineral structure, is added to the sorbed water. The resulting water reacts with the surface of the solid phase, and the surface of the grain is dissolved. However, it is possible that with dehydration, cations can be extracted from the crystal lattice and re-

\section{REFERENCES}

1. Boyd R., Barnes S.J., De Caritat P., Chekushin V.A., Melezhik V.A., Reimann, C., Zientek, M.L. Emissions from the copper-nickel industry on the Kola Peninsula and at Noril'sk, Russia. Atmospheric Environment, 2009, vol. 43, pp. 1474-1480.

2. Šrerbula S.M., Živković D.T., Radojević A.A., Kalinović T.S., Kalinović J.V. Emission of $\mathrm{SO}_{2}$ and $\mathrm{SO}_{4}$ from copper smelter and its influence on the level of total $\mathrm{S}$ in soil and moss in Bor, Serbia, and the surroundings. Chemical industry, 2015, vol. 69, no. 1, pp. 51-58.

3. Stovern M., Felix O., Csavina J., Rine K.P., MacKenzie R., Russell M.R., Robert M., Jones R.M., King M., Betterton E.A., Saez A.E. Simulation of windblown dust transport from a mine tailings impoundment using a computational fluid dynamics model. Aeolian Resources, 2014, vol. 14, pp. 75-83.

4. Stovern M., Guzman H., Rine K.P., Felix O., King M., Ela W.P., Betterton E.A., Saez A.E. Windblown dust deposition forecasting and spread of contamination around mine tailings. Atmosfera, 2016, vol. 7, Iss. 2, no. 16. Available at: https://doi.org/10.3390/ atmos7020016 (accessed 15 November 2021).

5. Maseki J., Annegarn H.J., Spiers G. Health risk posed by enriched heavy metals (as, $\mathrm{Cd}$, and $\mathrm{Cr}$ ) in airborne particles from Witwatersrand gold tailings. Journal of the Southern African Institute of Mining and Metallurgy, 2017, vol. 117, no. 7, pp. 663-669.

6. Bisquert D.S., Castejon J.M.P., Fernandez G.G. The impact of atmospheric dust de- position and trace elements levels on the villages surrounding the former mining areas in a semi-arid environment (SE Spain). Atmospheric Environment, 2017, vol. 152, pp. 256-269.

7. Djebbi C., Chaabani F., Font O., Queralt I., Querol X. Atmospheric dust deposition on soils around an abandoned fluorite mine (Hammam Zriba, NE Tunisia). Environmental Resourses, 2017, vol. 158, pp. 153-166.

8. Gerding J., Novoselov A.A., Morales J. Climate and pyrite: two factors to control the evolution of abandoned tailings in Northern placed by protons. This is evidenced by a high concentration of elements in condensates from $\mathrm{Cu}$ - and $\mathrm{Zn}$-sulfates.

\section{Conclusion}

By analyzing the condensates, it was determined that a wide range of chemical elements can migrate with vaporgas streams from secondary hydrous sulfates under

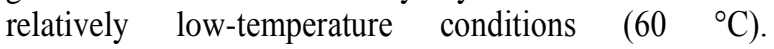
Condensate from the wet sample contains high element concentrations due to the input of elements from the pore solution and hydrous sulfates.

Vapor from the dry sample consists of sorbed and structural water. The destruction of goslarite, sideronatrite, cyanochroite, and siderotil with the separation of water occurs at $40{ }^{\circ} \mathrm{C}$. Structural water separates from these minerals, after which new minerals are formed (gunningite $\mathrm{ZnSO}_{4} \times \mathrm{H}_{2} \mathrm{O}$ from goslarite $\mathrm{Zn}\left(\mathrm{SO}_{4}\right) \times 7 \mathrm{H}_{2} \mathrm{O}$, Na-jarosite $\mathrm{NaFe}_{3}\left(\mathrm{SO}_{4}\right)_{2}(\mathrm{OH})_{6}$ from sideronatrite $\mathrm{Na}_{2} \mathrm{Fe}\left(\mathrm{SO}_{4}\right)_{2}(\mathrm{OH}) \times 3 \mathrm{H}_{2} \mathrm{O}$, and poitevinite $(\mathrm{Cu}, \mathrm{Fe}) \mathrm{SO}_{4} \times \mathrm{H}_{2} \mathrm{O}$ and brochantite $\mathrm{Cu}_{4}\left(\mathrm{SO}_{4}\right)(\mathrm{OH})_{6}$ from cyanochroite). Antlerite, gunningite and starkeyite remain stable over the studied temperature range (up to $50^{\circ} \mathrm{C}$ ).

Alterations in mineral structure and water release are indicated by losses of sample weight. With dehydration, cations and trace elements can be extracted from the crystal lattice, replaced by protons, and can then enter the vapor-gas phase when the solution evaporates.

This research was financially supported by RFBR (grant no. 20-05-00126) and State assignment of IPGG SB RAS (project no. 0331-2019-0031). The authors gratefully thank anonymous reviewer for helpful comments and recommendations on this manuscript.

Chile. Journal of Geochemical Exploration, 2021, vol. 221, p. 106686.

9. Fattahi S.M., Soroush A., Huang N., Zhang J., Yu Y., Jodari Abbasi S. Durability of biotechnologically induced crusts on sand against wind erosion. Journal of Arid Environments, 2021, vol. 189 , p. 104508.

10. Csavina J., Taylor M.P., Félix O., Rine K.P., Sáez A.E., Betterton E.A. Size-resolved dust and aerosol contaminants associated with copper and lead smelting emissions: implications for emission management and human health. Science of Total Environment, 2014, vol. 493, pp. 750-756.

11. Sanchez de la Campa A.M., Sanchez-Rodas D., Gonzalez Castanedo Y., de la Rosa J.D., Geochemical anomalies of toxic elements and arsenic speciation in airborne particles from $\mathrm{Cu}$ mining and smelting activities: Influence on air quality. Journal of Hazards Material, 2015, vol. 291, pp. 18-27.

12. González-Castanedo Y., Moreno T., Rocío Fernández-Camacho R., Sanchez de la Campa AnaMaría, Alastuey A., Querol X., Rosa J. Size distribution and chemical com- position of particulatematter stackemissions in and around a copper smelter. Atmospheric Environment, 2014, vol. 98, pp. 271-282.

13. Gopalapillai Y., Kirk J.L., Landis M. S., Muir D.C., Cooke C.A., Gleason A., Allie Ho Kelly E., Schindler D., Wang X., Lawson G. Source analysis of pollutant elements in winter air deposition in the Athabasca oil sands region: A temporal and spatial study. ACS Earth Space Chemistry, 2019, vol. 3, no. 8, pp. 1656-1668.

14. Dall'Osto M., Beddows D.C.S., Asmi A., Poulain L., Hao L., Freney E., Allan J.D., Canagaratna M., Crippa M., Bianchi F., de Leeuw G., Eriksson A., Swietlicki E., Hansson H.C., Henzing J.S., Granier C., Zemankova K., Laj P., Onasch T., Prevot A., Putaud J.P., Sellegri K., Vidal M., Virtanen A., Simo R., Worsnop D., O'Dowd C., Kulmala M., Harrison R.M. Novel insights on new particle formation derived from a pan-european observing system. Science Report, 2018, vol. 8, no. 1482. DOI: 10.1038/s41598-017-17343-9 
15. Csavina J., Field J., Taylor M.P., Gao S., Landázuri A., Betterton E.A., Sáez A.E. A review on the importance of metals and metalloids in atmospheric dust and aerosol from mining operations. Science of Total Environment, 2012, vol. 433, pp. 58-73.

16. Ritchie A.I.M. Oxidation and gas transport in piles of sulfidic material. Environmental aspects of mine wastes. Eds. J.L. Jambor, D.W. Blowes, A.I.M. Ritchie. Vancouver, BC, 2003. Vol. 31, pp. 73-94.

17. Martin V., Aubertin M., Bussière B., Mbonimpa M., Dagenais A.M. Gosselin M. Measurement of oxygen consumption and diffusion in exposed and covered reactive mine tailings. Proceedings of 7 th ICARD. St. Louis MO, USA, 2006. pp. 1156-1169.

18. Binning P.J., Postma D., Russell T.F., Wesselingh J.A., Boulin P.F. Advective and diffusive contributions to reactive gas transport during pyrite oxidation in the unsaturated zone. Water Resources Research, 2007, vol. 43, Iss. 2, no. W02414. DOI: 10.1029/2005WR004474

19. Vriens B., Arnault M.S., Laurenzi L., Smith L., Mayer K.U., Beckie R.D. Localized sulfide oxidation limited by oxygen supply in a full-scale waste-rock pile. Vadose Zone Journal, 2018, vol. 17, Iss. 1, no. 180119. DOI: 10.2136/vzj2018.06.0119

20. Cabassi J., Tassi F., Venturi S., Calabrese S., Capecchiacci F., D'Alessandro W., Vaselli O. A new approach for the measurement of gaseous elemental mercury (GEM) and $\mathrm{H}_{2} \mathrm{~S}$ in air from anthropogenic and natural sources: Examples from Mt. Amiata (Siena, Central Italy) and Solfatara Crater (Campi Flegrei, Southern Italy) Journal of Geochemical Exploration, 2017, vol. 175, pp. 48-58.

21. Nacht D.M., Gustin M.S., Engle M.A., Zehner R.E., Giglini A.D. Atmospheric mercury emissions and speciation at the Sulphur Bank Mercury Mine Superfund Site, Northern California. Environmental Science Technology, 2004, vol. 38, pp. 1977-1983.

22. Eckley C.S., Gustin M., Marsik F., Miller M.B. Measurement of surface mercury fluxes at active industrial gold mines in Nevada (USA). Science of Total Environment, 2011, vol. 409, pp. 514-522

23. Miller M.B., Gustin M.S. Gas-exchange chamber analysis of elemental mercury deposition/emission to alluvium, ore, and mine tailings. Chemosphere, 2015, vol. 131, pp. 209-216.

24. Porstendörfer J. Properties and behaviour of radon and thoron and their decay products in the air. Journal Aerosol Science, 1994, vol. 25, pp. 219-263.

25. Gee K.F., Poon H.Y., Hashisho Z., Ulrich A.C. Effect of naphtha diluent on greenhouse gases and reduced sulfur compounds emissions from oil sands tailings. Science of Total Environment, 2017, vol. 598, pp. 916-924.

26. Hale M. Mineral deposits and chalcogen gases. Mineral Mag., 1993, vol. 57, pp. 599-606.

27. Hale M. Gas geochemistry and deeply buried mineral deposits: the contribution of the applied geochemistry research group, Imperia College of Science and Technology, London. Geochemistry: exploration, environment, analysis, 2010, vol. 10, pp. 261-267.

28. Zhou C., Liu G., Wu S., Lam P.K.S. The environmental characteristics of usage of coal gangue in bricking-making: a case study at Huainan, China. Chemosphere, 2014, vol. 95, pp. 274-280.

29. Sánchez-Rodas D., Alsioufi L., Sánchez de la Campa A.M., González-Castanedo Y. Antimony speciation as geochemical tracer for anthropogenic emissions of atmospheric particulate matter. J. Hazard. Mater., 2017, vol. 324, pp. 213-220.

30. Vinogradova, I.V. Paroobraznye ionnye formy elementov $v$ pochvennom vozdukhe i prizemnoy atmosfere kak indikatory rudnykh mestorozdeniy i ecologicheskoy situatsii. Avtoreferat Dis. Kand. nauk [Vapor ionic forms of elements in soils air and in ground layer of atmosphere as a indicators of ore deposit and ecological situation. Cand. Diss. Abstract]. St. Peterburg, 1995. 22 p

31. Larocque A.C.L., Rasmussen P.E. An overview of trace metals in the environment, from mobilization to remediation. Environmental Geology, 1998, vol. 33, no. 2, pp. 85-91.

32. Bortnikova S.B., Olenchenko V.V., Gaskova O.L., Chernii K.I., Devyatova A.Yu., Kucher D.P. Evidence of trace element emission during the combustion of sulfidebearing metallurgical slags. Applied Geochemistry, 2017, vol. 78, pp. 105-115.
33. Bortnikova S.B., Yurkevich N.V., Abrosimova N.A., Devyatova A.Y., Edelev A.V., Makas A.L., Troshkov M.L. Assessment of emissions of trace elements and sulfur gases from sulfide tailings. Journal Geochemical Exploration, 2018, vol. 186, pp. 256-269.

34. Bortnikova S., Yurkevich N., Devyatova A., Saeva O., Shuvaeva O., Makas A., Troshkov M., Abrosimova N., Kirillov M., Korneeva T., Kremleva T. Mechanisms of low-temperature vapor-gas streams formation from sulfide mine waste. Science of Total Environment, 2019, vol. 647, pp. 411-419.

35. Bortnikova S., Yurkevich N., Devyatova A., Abrosimova N., Saeva O., Cherny N., Troitskii D. Transfer of chemical elements in vapor-gas streams at the dehydration of secondary sulfates. E3S Web of Conferences, 2019, vol. 98, p. 05004

36. Bortnikova S., Abrosimova N., Yurkevich N., Zvereva V., Devyatova A., Gaskova O., Saeva O., Korneeva T., Shuvaeva O., Pal'chik N., Chernukhin V., Reutsky A. Gas transfer of metals during the destruction of efflorescent sulfates from the Belovo Plant Sulfide Slag, Russia. Minerals, 2019, vol. 9, Iss. 6, no. 344.

37. Jambor J.L., Nordstrom D.K., Alpers C.N. Metalsulphate salts from sulphide mineral oxidation. Reviews in Mineralogy \& Geochemistry, 2000, vol. 40, pp. 303-350.

38. Gas'kova O.L., Shironosova G.P., Bortnikova S.B. Thermodynamic estimation of the stability field of bukovskyite, an iron sulfoarsenate. Geochemistry International, 2008, vol. 46, pp. 85-91.

39. Bortnikova S.B., Yurkevich N.V., Gaskova O.L., Devyatova A.Y., Novikova I.I., Volynkin S.S., Mytsik A.V., Podolinnaya V.A. Element transfer by a vapor-gas stream from sulfide mine tailings: from field and laboratory evidence to thermodynamic modeling. Environmental Science and Pollution Research, 2021. vol. 28. pp. 14927-14942.

40. Bortnikova S., Gaskova O., Yurkevich N., Saeva O., Abrosimova $\mathrm{N}$. Chemical treatment of highly toxic acid mine drainage at a gold mining site in Southwestern Siberia, Russia. Minerals, 2020, vol. 10, pp. 1-23.

41. Olenchenko V.V., Osipova P.S., Yurkevich N.V., Bortnikova S.B. Electrical resistivity dynamics beneath the weathered mine tailings in response to ambient temperature. Journal of Environmental and Engineering Geophysics, 2020, vol. 25. pp. 55-63.

42. Sidenko N.V., Giere R., Bortnikova S.B., Cottard F., Palchik N.A. Mobility of heavy metals in self-burning waste heaps of the zinc smelting plant in Belovo (Kemerovo Region, Russia). Journal of Geochemical Exploration, 2001, vol. 74, no. 1-3, pp. 109-125.

43. Bortnikova S., Manstein Yu., Saeva O., Yurkevich N., Gaskova O., Bessonova E., Romanov R., Ermolaeva N., Chernuhin V., Reutsky A. Acid mine drainage migration of Belovo Zinc Plant (South Siberia, Russia): multidisciplinary study. Water security in the Mediterranean Region. An International Evaluation of Management, Control, and Governance Approaches. Eds. A. Scozzari, B. Mansouri. Netherlands, Springer, 2011. pp. 191-208.

44. Piminov P.A., Baranov G.N., Bogomyagkov A.V. Synchrotron radiation research and application at VEPP-4. Physics Procedia, 2016, vol. 84, pp. 19-26.

45. Woods T.L., Garrels R.M. Thermodynamic values at low temperature for natural inorganic materials: an uncritical summary. New York, Oxford University Press, 1987, $284 \mathrm{p}$.

46. Yokokawa $\mathrm{H}$. Tables of thermodynamic properties of inorganic compounds. Journal of the National Chemical Laboratory for Industry, 1988, vol. 83, pp. 27-121.

47. Chudnenko K.V. Termodinamicheskoe modelirovanie v geokhimii; teoriya, algoritmy, programnoe obespechenie, prilozheniya [Thermodynamic modeling in geochemistry: theory, algorithms, software, applications.] Novosibirsk, PH Geo Publ., 2010. 283 p.

48. Anderson J.L., Peterson R.C. Swainson I.P. Combined neutron powder and X-ray single-crystal diffraction refinement of the atomic structure and hydrogen bonding of goslarite $\left(\mathrm{ZnSO}_{4} \times 7 \mathrm{H}_{2} \mathrm{O}\right)$. Mineralogy Magazine, 2005, vol. 69, no. 3, pp. 259-271.

49. Chou M., Seal R.R. Determination of goslarite-bianchite equilibria by the humidity-buffer technique at $0.1 \mathrm{MPa}$. Chemical Geology, 2005 , vol. 215 , no. $1-4$, pp. 517-523. 
Information about the authors

Svetlana B. Bortnikova, Dr. Sc., professor, Trofimuk Institute of Petroleum Geology and Geophysics of the Siberian Branch of the RAS.

Natalya A. Abrosimova, Cand. Sc., researcher, Trofimuk Institute of Petroleum Geology and Geophysics of the Siberian Branch of the RAS .

Anna Yu. Devyatova, Cand. Sc., senior researcher, Trofimuk Institute of Petroleum Geology and Geophysics of the Siberian Branch of the RAS.

Elizaveta P. Shevko, Dr. Sc., senior researcher, Sobolev Institute of Geology and Mineralogy of the Siberian Branch of the RAS.

Nataliya V. Yurkevich, Cand. Sc., leading researcher, Trofimuk Institute of Petroleum Geology and Geophysics of the Siberian Branch of the RAS.

Nikolay K. Cherny, engineer, Trofimuk Institute of Petroleum Geology and Geophysics of the Siberian Branch of the RAS.

Irina V. Danilenko, Cand. Sc., researcher, Sobolev Institute of Geology and Mineralogy of the Siberian Branch of the RAS.

Nadezhda A. Palchik, Cand. Sc., senior researcher, Sobolev Institute of Geology and Mineralogy of the Siberian Branch of the RAS. 
УДК 550.46

\title{
ЛЕТУЧЕСТЬ ХИМИЧЕСКИХ ЭЛЕМЕНТОВ ПРИ ДЕГИДРАЦИИ ВТОРИЧНЫХ СУЛЬФАТОВ
}

\section{Бортникова Светлана Борисовна 1 , BortnikivaSB@ipgg.sbras.ru}

\section{Абросимова Наталья Александровна ${ }^{1}$,} AbrosimovaNA@ipgg.sbras.ru

Девятова Анна Юрьевна ${ }^{1}$, DevyatovaAY@ipgg.sbras.ru

\section{Шевко Елизавета Павловна², Liza@igm.nsc.ru}

\author{
Юркевич Наталия Викторовна ${ }^{1}$, \\ YurkevichNV@ipgg.sbras.ru
}

\author{
Черный Николай Константинович 1 \\ wulfgar.nk@gmail.com
}

Даниленко Ирина Владимировна², iv_danilenko@igm.nsc.ru

\section{Пальчик Надежда Арсентьевна²,} nadezhda@igm.nsc.ru

1 Институт нефтегазовой геологии и геофизики им. А.А. Трофимука СО РАН, Россия, 630090, г. Новосибирск, пр. Ак. Коптюга, 3.

2 Институт геологии и минералогии им. С.Л. Соболева Сибирского отделения РАН, Россия, 630090, г. Новосибирск, пр. Ак. Коптюга, 3.

\begin{abstract}
Актуальность. Загрязнение воздуха в результате деятельности горнодобывающей и металлургической промышленности является серьезной проблемой для окружающей среды. Это исследование проводилось с целью определения возможных механизмов миграции и источников элементов в атмоссрере над поверхностью хвостохранилищ.

Основная цель исследования - показать, что химические элементы могут захватьваться водяным паром и могут мигрировать с паровой фразой во время десорбции и дегидратации водных сульфатов.

объект: образцы с поверхности отвалов, Белово (Беловский цинкозавод, Белово, Россия).

Методы. Порошковая рентгеновская дифррактометрия (XRD) использовалась для определения фазового состава кристаллических веществ, их количественных фразовых соотношений и превращений. Для определения элементов в пробах воды (поровый раствор и конденсаты) использовали прибор Agilent 8800 ICP-MS (Токио, Япония), оборудованный распылителем MicroMist. Также использовались бинокулярньй микроскоп и методы физико-химического моделирования.

Результаты. Путем анализа конденсатов было определено, что широкий спектр химических элементов может мигрировать с парогазовыми потоками из вторичных гидросульфратов в относительно низкотемпературных условиях $\left(60^{\circ} \mathrm{C}\right)$. Конденсат влажного образца содержит высокие концентрации элементов из-за поступления элементов из порового раствора и водных сульфратов. На изменение минеральной структуры и выделение воды указывает потеря веса пробы. При дегидратаиии катионы и микроэлементы могут быть извлечены из кристаллической решетки, заменены протонами и затем могут перейти в парогазовую фазу при испарении раствора.
\end{abstract}

Ключевые слова:

Вторичные сульфраты, поровый раствор, конденсаты, хвостохранилища, летучесть химических элементов.

Работа выполнена при финансовой поддержке РФФИ (грант № 20-05-00126) и в рамках Гос. задания ИНГГ СО РАН, проект № 0331-2019-0031.

\section{Информация об авторах}

Бортникова Светлана Борисовна, доктор геолого-минералогических наук, профессор, Институт нефтегазовой геологии и геофизики им. А.А. Трофимука СО РАН

Абросимова Наталья Александровна, кандидат геолого-минералогических наук, научный сотрудник Института нефтегазовой геологии и геофизики им. А.А. Трофимука СО РАН.

Девятова Анна Юрьевна, кандидат геолого-минералогических наук, старший научный сотрудник, Институт нефтегазовой геологии и геофизики им. А.А. Трофимука СО РАН.

Шевко Елизавета Павловна, доктор геолого-минералогических наук, старший научный сотрудник Института геологии и минералогии им. С.Л. Соболева Сибирского отделения РАН.

Юркевич Наталия Викторовна, кандидат геолого-минералогических наук, ведущий научный сотрудник, Институт нефтегазовой геологии и геофизики им. А.А. Трофимука СО РАН.

Черный Николай Константинович, инженер, аспирант, Институт нефтегазовой геологии и геофизики им. Трофимука СО РАН

Даниленко Ирина Владимировна, кандидат геолого-минералогических наук, научный сотрудник Института геологии и минералогии им. С.Л. Соболева Сибирского отделения РАН.

Пальчик Надежда Арсентьевна, кандидат геолого-минералогических наук, старший научный сотрудник Института геологии и минералогии им. С.Л. Соболева Сибирского отделения РАН. 